Article

\title{
Phytochemical Composition, Hepatoprotective, and Antioxidant Activities of Phyllodium pulchellum (L.) Desv
}

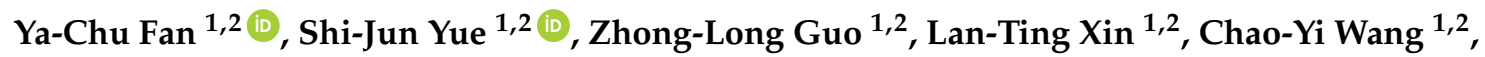 \\ Dong-Lin Zhao ${ }^{1,3}$, Hua-Shi Guan ${ }^{1,2, *}$ and Chang-Yun Wang ${ }^{1,2, *}$ \\ 1 Key Laboratory of Marine Drugs, The Ministry of Education of China, School of Medicine and Pharmacy, \\ Ocean University of China, Qingdao 266003, China; fanyachu@163.com (Y.-C.F.); \\ shijun_yue@163.com (S.-J.Y.); 15726227761@163.com (Z.-L.G.); xinlanting1993@163.com (L.-T.X.); \\ chaoyi0411@126.com (C.-Y.W.); zhaodonglin@caas.cn (D.-L.Z.) \\ 2 Laboratory for Marine Drugs and Bioproducts, Qingdao National Laboratory for Marine Science and \\ Technology, Qingdao 266071, China \\ 3 Marine Agriculture Research Center, Tobacco Research Institute of Chinese Academy of Agricultural \\ Sciences, Qingdao 266101, China \\ * Correspondence: hsguan@ouc.edu.cn (H.-S.G.), changyun@ouc.edu.cn (C.-Y.W.); \\ Tel./Fax: +86-532-8203-1667 (H.-S.G.); +86-532-8203-1536 (C.-Y.W.)
}

Received: 17 April 2018; Accepted: 4 June 2018; Published: 5 June 2018

\begin{abstract}
Phyllodiumpulchellum has been traditionally used as a medicinal herb because of its health-promoting effects, such as its hepatoprotective and antioxidant activities. In the present study, the petroleum ether fraction, ethyl acetate fraction, $n$-butanol fraction, and aqueous fraction were successively obtained from the ethanol extract of P. pulchellum. Two fractions, ethyl acetate fraction and $n$-butanol fraction, were found to display hepatoprotective and antioxidant activities. Further chemical investigation of the active fractions led to the isolation of its main constituents, including 11 flavonoids (1-11) and 8 indole alkaloids (12-19). There were 9 flavonoids (1-9) that were obtained from the ethyl acetate fraction, and 2 flavonoids (10 and 11) and 8 alkaloids (12-19) from the $n$-butanol fraction. Compounds 1-11 and 16-19 were isolated for the first time from P. pulchellum, and 1, 2, 8, 11, and 18 were obtained from the genus Phyllodium initially. Subsequently, the isolated compounds were evaluated for their in vitro hepatoprotective effects on the human normal hepatocyte cell line L-O2 injured by D-galactosamine and radical scavenging activities against 1,1-diphenyl-2-picrylhydrazyl (DPPH). The flavonoids (-)-epigallocatechin (5) and (-)-epicatechin (6) exhibited prominent hepatoprotective activities with higher cell viability values $\left(65.53 \%\right.$ and $62.40 \%$ at $10 \mu \mathrm{M} \cdot \mathrm{mL}^{-1}$, respectively) than the positive control, silymarin $\left(61.85 \%\right.$ at $\left.10 \mu \mathrm{M} \cdot \mathrm{mL}^{-1}\right)$. In addition, compared with the positive control of vitamin $\mathrm{C}\left(\mathrm{IC}_{50}\right.$ : $\left.5.14 \mu \mathrm{g} \cdot \mathrm{mL}^{-1}\right),(-)$-gallocatechin (3) and (-)-epigallocatechin (5) exhibited stronger antioxidant activities with $\mathrm{IC}_{50}$ values of 3.80 and $3.97 \mu \mathrm{g} \cdot \mathrm{mL}^{-1}$, respectively. Furthermore, the total flavonoids from P. pulchellum were characterized using a high-performance liquid chromatography-linear ion trap quadrupole-Orbitrap-mass spectrometry (HPLC-LTQ-Orbitrap-MS). In total, 34 flavonoids were tentatively identified, which had not been previously reported from P. pulchellum. In addition, we performed a semi-quantitative analysis of the isolated flavonoids. The contents of compounds 1-11 were $3.88,17.73,140.35,41.93,27.80,4.34,0.01,0.20,9.67,795.85$, and $5.23 \mu \mathrm{g} \cdot \mathrm{g}^{-1}$, respectively. In conclusion, this study revealed that the flavonoids that were isolated from P. pulchellum showed hepatoprotective and antioxidant activities, indicating that, besides alkaloids, the flavonoids should be the potential pharmacodynamic ingredients that are responsible for the hepatoprotective and antioxidant activities of P. pulchellum.
\end{abstract}


Keywords: Phyllodium pulchellum; flavonoids; hepatoprotective; antioxidant; HPLC-LTQ-Orbitrap-MS

\section{Introduction}

Phyllodium pulchellum (L.) Desv., once classified as Desmodium genus, is a shrub belonging to the Phyllodium genus, family Papilionoideae. It is mainly distributed in Southern China [1] and India [2]. As a traditional Chinese medicine, it has been used for the treatment of the enlargement of the liver and spleen, cold fever, malaria, rheumatism bone pains, and swelling [3]. The crude extract of P. pulchellum was found to possess antifibrotic [4], antioxidant [5], antitumor [6], antidiarrhea [3], antihypertensive [7], and antiarrhythmic [8] activities. Furthermore, the total alkaloids that were isolated from P. pulchellum also exhibited significant antifibrotic activity [9-11] and monoamine oxidase inhibitory activity [12].

Over the past five decades, a few chemical constituents were isolated and identified from P. pulchellum by various chromatographic, MS, and NMR technologies. There have been 18 alkaloids that have been reported, namely, $N, N$-dimethyltryptamine, gramine, 5-hydroxy- $N, N$-dimethyltryptamine, 5-hydroxy- $N$-methyltryptamine, 5-methoxy- $N, N$-dimethyltryptamine, 5-methoxy- $N$-methyltryptamine, $N, N$-dimethyltryptamine oxide, 5-methoxy- $N, N$-dimethyltryptamine-oxide, 5-hydroxy- $N, N$ dimethyltryptamine-oxide, $\quad N, N, N$-trimethyltryptamine, $\quad 5$-methoxy- $N, N, N$-trimethyl- $1 H$-indole3ethanaminium, 1-methyl-9H-pyrido[3,4- $b$ ]indol-2-ium, 6-methoxy-1,2-dimethyl-9H-pyrido[3,4- $b$ ]indol2 -ium, 1,2-dimethyl-1,2,3,4-tetrahydro- $\beta$-carboline, 6-methoxy-2-methyl-1,2,3,4-tetrahydro- $\beta$-carboline, 3-indolcarbaldehyde, 3-indolcarbaldehyde, and uridine [7,12-15]. There have been 6 flavonoids, namely, pulcheloid B, citrusinol, yukovanol, 3,5,2', 4'-tetrahydroxy-2,2"'-dimethylpyrano-[5", $\left.6^{\prime \prime}, 7,8\right]$ flavanone, citflavanone, and 8-prenylated 5,7,3',4'-tetrahydroxy flavanone $[6,14,16]$, that have been reported. There have been 16 phenols that have been found, namely, pulchelstyrenes A-F, 4-hydroxy-2,3-dimethoxybenzaldehyde, p-hydroxybenzoic acid, protocatechuic acid, 2-O-(3,4dihydroxybenzoyl)-2,4,6-trihydroxyphenylacetic acid, protocatechuic acid methyl ester, protocatechuic acid ethyl ester, gallic acid ethyl ester, $p$-coumaric acid, caffeic acid ester, and arbutin [6,14-16]. There have been 2 glycosides, galactomannan and physcion 1-glycosyl rhamnoside [17,18], that have been reported, as well as 1 lignan derivative methyl piperitol [6], 1 steroid daucosterol [15], and 1 terpene loliolide [15]. Among them, alkaloids have been recognized asing be the active constituents that are responsible for the hepatoprotective activity of this species [7]. The quality control of P. pulchellum was established by detecting $N, N$-dimethyltryptamine and 5-methoxy- $N, N$-dimethyltryptamine with an HPLC-DAD. The results showed that the highest contents of $N, N$-dimethyltryptamine and 5-methoxy-N,N-dimethyltryptamine in the roots of the P. pulchellum that were collected in September from Guangxi, China, were 0.106 and $3.260 \mathrm{~g} \times 100 \mathrm{~g}^{-1}$, respectively [19]. However, little is known about the bioactivity of other types of compounds from P. pulchellum.

This study attempted to investigate the main hepatoprotective and antioxidant ingredients of P. pulchellum. Four fractions, namely, the petroleum ether fraction (PPP), ethyl acetate fraction (PPE), n-butanol fraction (PPB), and aqueous fraction (PPA), were successively obtained from the ethanol extract of $P$. pulchellum. These four fractions were screened for their hepatoprotective and antioxidant activities. As the PPE and PPB showed the hepatoprotective and antioxidant activities, we further investigated the active principles from the target fractions. Subsequently, the structure elucidation, biological activities, and structure-activity relationships of the isolated compounds were studied and discussed. It was indicated that, besides the alkaloids, the flavonoids could be another potential pharmacodynamic ingredient for driving the hepatoprotective and antioxidant activities of P. pulchellum. Because the flavonoids showed good activities, we further investigated the composition of the total flavonoids of P. pulchellum using high-performance liquid chromatography-linear ion trap quadrupole-Orbitrap-mass spectrometry (HPLC-LTQ-Orbitrap-MS). It was the first report to characterize the flavonoid compositions of P. pulchellum by LC-MS. 


\section{Materials and Methods}

\subsection{Plant Material}

The aerial parts of the P. pulchellum were collected from Xingning (GPS coordinates: N $23^{\circ} 50^{\prime}$, E $115^{\circ} 30^{\prime}$ ), Guangdong, China, in July 2014, and were identified by Professor Fengqin Zhou, Shandong University of Chinese Medicine. A voucher specimen (No. PP-201407) was deposited at the Key Laboratory of Marine Drugs, the Ministry of Education of China, Ocean University of China, Qingdao, China.

\subsection{Reagents}

Methanol (MeOH, HPLC grade), ethanol, acetone, petroleum ether (PE), ethyl acetate (EtOAc), $n$-butanol $(n-\mathrm{BuOH})$, and dichloromethane $\left(\mathrm{CH}_{2} \mathrm{Cl}_{2}\right)$ were purchased from Tianjin Siyou Chemical Reagent Co., Ltd. (Tianjin, China). The HPLC-grade acetonitrile was acquired from Fisher Scientific (Fair Lawn, NJ, USA). The formic acid (HPLC grade) was purchased from Sigma Aldrich (St. Louis, MO, USA). The D-Glucose, L-glucose, L-rhamnose, silymarin, dimethyl sulfoxide (DMSO), and 1,1-diphenyl-2-picrylhydrazyl (DPPH) were the products of Sigma (St. Louis, MO, USA). The Dulbecco modified eagle medium (DMEM) was purchased from GIBCO (Carlsbad, CA, USA). The calf serum was purchased from Hangzhou Sijiqing Biological Engineering Materials Co., Ltd. (Hangzhou, China). The phosphate buffer saline (PBS), trypsin-EDTA solution, and penicillin and streptomycin mixture were obtained from Nanjing Kaiji Biotechnology Development Co., Ltd. (Nanjing, China). The human normal hepatocyte cell line L-O2 were purchased from the Cell Resource Center, IBMS, CAMS/PUMC (Beijing, China). The D-galactosamine (D-GalN) was purchased from Wako Co., Ltd. (Tokyo, Japan). The 3-(4,5-dimethyl-2-thiazolyl)-2,5-diphenyl-2-H-tetrazolium bromide (MTT) was purchased from Biosharp (Hefei, China). The vitamin C was a product of the Sinopharm Group Chemical Reagent Co., Ltd. (Beijing, China). The rutin was purchased from the National Institutes for Food and Drug Control (Beijing, China).

\subsection{General Experimental Procedures}

Optical rotations were measured on a JASCO P-1020 digital polarimeter (JASCO Corporation, Tokyo, Japan). The IR spectra were recorded on a Nicolet-Nexus-470 spectrometer (Nicolet Corp., Madison, WI, USA). The NMR spectra were recorded on an Agilent DD2 $500 \mathrm{MHz}$ NMR spectrometer (500 MHz for ${ }^{1} \mathrm{H}$ and $125 \mathrm{MHz}$ for ${ }^{13} \mathrm{C}$ ), using TMS as an internal standard (Agilent Technologies, Santa Clara, CA, USA). The ESI-MS spectra were obtained from a Micromass Q-TOF spectrometer (Waters Corp., Milford, MA, USA). The HPLC-LTQ-Orbitrap-MS analysis was performed on an Agilent series 1290 Infinity HPLC instrument (Agilent, Technologies, Santa Clara, CA, USA), coupled with an LTQ/Orbitrap mass spectrometer (Thermo Scientific, Bremen, Germany) that was equipped with an electrospray (ESI) interface. The semipreparative HPLC was performed using a Hitachi prep-HPLC system that was coupled with a Hitachi L-2455 diode array detector (Hitachi Corp., Tokyo, Japan) and a Kromasil C-18 preparative HPLC column $(250 \mathrm{~mm} \times 10 \mathrm{~mm}, 5 \mathrm{~mm})$ (Eka Nobel, Bohus, Sweden). Silica gel (Qing Dao Hai Yang Chemical Group Co., Qingdao, China; 200-300 mesh) and Sephadex LH-20 (Amersham Biosciences, Inc., Piscataway, NJ, USA) were used for column chromatography. The pre-coated silica gel plates (Yantai Zifu Chemical Group Co., Yantai, China; G60 and F-254) were used for thin-layer chromatography.

\subsection{Extraction and Isolation}

The dried aerial parts of the P. pulchellum $(8.0 \mathrm{~kg})$ were consecutively extracted three times by reflux, with $95 \%$ ethanol at $80{ }^{\circ} \mathrm{C}$ for $3 \mathrm{~h}$. The combined ethanol layer was lyophilized in order to obtain the ethanol extract $(950 \mathrm{~g})$. This dried residue was mixed with distilled water $(1000 \mathrm{~mL})$ and successively partitioned three times with the same volume of petroleum ether (PE), EtOAc, and $n$-butanol (n-BuOH). The respective fractions were dried under reduced pressure and lyophilized to yield four fractions, namely, PPP (60.0 g), PPE (50.0 g), PPB (30.0 g), and PPA (20.0 g). The above fractions were stored at $-20^{\circ} \mathrm{C}$. 
The PPE (40.0 g) was purified using a vacuum liquid chromatography (VLC) on silica gel, using a step gradient elution with EtOAc/PE (0-100\%), so as to afford six fractions (Fractions 1-6). Fraction 3 was applied to a silica gel column chromatography with $\mathrm{CH}_{2} \mathrm{Cl}_{2} / \mathrm{MeOH}$ (50:1 to 0:100), in order to provide 12 subfractions (subfrations 3.1-3.12). Subfraction 3.5 was isolated using a Sephadex LH-20 column with mixtures of $\mathrm{CH}_{2} \mathrm{Cl}_{2} / \mathrm{MeOH}(1: 1)$ and preparative $\mathrm{HPLC}$ with $50 \% \mathrm{MeOH}$ to produce compound $8(5.7 \mathrm{mg})$. Subfraction 3.7 was subjected to a silica gel column with $\mathrm{PE} / \mathrm{CH}_{2} \mathrm{Cl}_{2} / \mathrm{MeOH}$ (2:1:1) in order to yield compound $9(30.0 \mathrm{mg})$. Subfraction 3.12 was purified using a Sephadex LH-20 column with $\mathrm{CH}_{2} \mathrm{Cl}_{2} / \mathrm{MeOH}$ (1:1), and was finally purified using preparative HPLC with $30 \% \mathrm{MeOH}$ to obtain compound 7 (13.8 mg). Fraction 4 was subjected to a silica gel column with $\mathrm{CH}_{2} \mathrm{Cl}_{2} / \mathrm{MeOH}(50: 1$ to 1:100) to afford six subfractions (subfraction 4.1-4.6). Subfraction 4.2 was applied to a Sephadex LH-20 column with $\mathrm{MeOH}$, followed by an octadecylsilyl (ODS) column chromatography with $\mathrm{MeOH} / \mathrm{H}_{2} \mathrm{O}$ (30:70 to 100:0) and preparative HPLC with 30\% MeOH, so as to obtain compounds 1 (53.0 mg) and 2 (12.5 mg). Subfraction 4.6 was separated under the same chromatography conditions as Subfraction 4.2, to afford compounds $3(7.7 \mathrm{mg}), 4(13.4 \mathrm{mg}), 5(11.2 \mathrm{mg})$, and 6 (51.0 mg).

The PPB (20.0 g) was separated into five fractions (fraction 1-5) by VLC, using a step gradient elution with $\mathrm{MeOH} / \mathrm{CH}_{2} \mathrm{Cl}_{2}(0-100 \%)$. Fraction 3 was subjected to a silica gel column with $\mathrm{CH}_{2} \mathrm{Cl}_{2} / \mathrm{MeOH} / \mathrm{NH}_{3} \cdot \mathrm{H}_{2} \mathrm{O}$ (30:1 to 0:100), to afford nine subfractions (subfraction 3.1-3.9). Subfraction 3.3 was applied to a Sephadex LH-20 column with MeOH and a preparation of thin-layer chromatography in order to obtain compounds $12(45.0 \mathrm{mg})$ and $14(13.0 \mathrm{mg})$. Subfraction 3.5 was separated under the same chromatography conditions as subfraction 3.3, to give compounds 13 (48.0 $\mathrm{mg})$ and $15(24.0 \mathrm{mg})$. Subfraction 3.9 was first subjected to a Sephadex LH-20 column with $\mathrm{MeOH}$ and an ODS column with $\mathrm{MeOH} / \mathrm{H}_{2} \mathrm{O}$ (30:70 to 100:0), and was further purified on preparative HPLC with 45\% MeOH, to yield compounds 16 (10.0 mg) and 17 (12.5 mg). Fraction 5 was subjected to a silica gel column using $\mathrm{CH}_{2} \mathrm{Cl}_{2} / \mathrm{MeOH}$ (50:1 to 0:100) to afford two subfractions (subfractions 5.1 and 5.2). Subfraction 5.1 was fractionated under the same chromatography conditions as subfraction 3.9, to provide compounds $10(12.6 \mathrm{mg})$ and $11(6.6 \mathrm{mg})$. Similarly, subfraction 5.2 was first subjected to a Sephadex LH-20 column with $\mathrm{MeOH}$, and was then separated by an ODS column with $\mathrm{MeOH} / \mathrm{H}_{2} \mathrm{O}$ (30:70 to 100:0), and was further purified on preparative HPLC with $20 \% \mathrm{MeOH}$ to form compounds $18(5.7 \mathrm{mg})$ and $19(2.7 \mathrm{mg})$.

\subsection{Hepatoprotective Activity Assay}

The hepatoprotective effects were tested on human normal hepatocyte cell line L-O2 injured by D-GalN using MTT method, as reported previously [20]. In this assay, the cell viability was measured so as to reflect the hepatoprotective activity. The cells were prepared into a $6.0 \times 10^{4} \cdot \mathrm{mL}^{-1}$ cell suspension with a DMEM medium containing $10 \%$ fetal bovine serum, penicillin $\left(100 \mathrm{U} \cdot \mathrm{mL}^{-1}\right)$, and streptomycin $\left(100 \mathrm{mg} \cdot \mathrm{mL}^{-1}\right)$, which were seeded in 96-well culture medium. After incubation for $24 \mathrm{~h}$ in an incubator with $5 \% \mathrm{CO}_{2}$ at $37{ }^{\circ} \mathrm{C}, 100 \mu \mathrm{L}$ test samples were added. After incubation for $1 \mathrm{~h}, 37 \mathrm{mM}$ D-GalN was added and incubated for $24 \mathrm{~h}$. The incubation solution was discarded, and $100 \mu \mathrm{L}$ MTT solution $\left(0.5 \mathrm{mg} \cdot \mathrm{mL}^{-1}\right)$ was added to each well, followed by incubation at $37^{\circ} \mathrm{C}$ for $4 \mathrm{~h}$. The supernatant was discarded and $150 \mu \mathrm{L}$ DMSO was added to each well so as to dissolve the fomazan particles. After a mild shaking, the optic density (OD) value was measured at the detection wavelength of $490 \mathrm{~nm}$. Silymarin (purity > 98\%) was used as a positive control. The blank control group was established at the same time, with $37 \mathrm{mM}$ D-GalN.

\subsection{DPPH Radical-Scavenging Activity Assay}

Radical reducing effects against DPPH were tested according to a previously described method [21]. The DPPH radical-scavenging was evaluated by comparing the percentage inhibition of the DPPH radicals. Specifically, for the fractions from P. pulchellum, each fraction of PPP, PPE, PPB, and PPA was dissolved in DMSO, and diluted into 156.25, 78.13, 39.06, 19.5, and 9.75 $\mu \mathrm{g} \cdot \mathrm{mL}^{-1}$, respectively. For the isolated compounds, each compound was dissolved in DMSO, and were diluted 
into 200, 100, 50, 25, and $12.5 \mu \mathrm{g} \cdot \mathrm{mL}^{-1}$. The DPPH solution was prepared with anhydrous ethanol to get the concentration of $0.05 \mathrm{mg} \cdot \mathrm{mL}^{-1}$. Each of the test samples were added to the DPPH solution $100 \mu \mathrm{L}$. After $30 \mathrm{~min}$ of dark reaction, the absorbance was measured at $517 \mathrm{~nm}$. DPPH radical reducing activity of the test sample was expressed as $I=\left[\left(A_{0} / A_{\mathrm{X}}\right) / A_{0}\right] \times 100 \%$, where $A_{0}$ was the absorbance of the blank control reaction and $A_{X}$ was the absorbance in the presence of the sample. The sample concentration, providing $50 \%$ inhibition $\left(\mathrm{IC}_{50}\right)$, was calculated from the regression equation that was prepared from the concentration of the samples and the inhibition percentage. Vitamin $\mathrm{C}$ (purity > $99.7 \%$ ) was used as a positive control.

\subsection{HPLC-LTQ-Orbitrap-MS Analysis}

The total flavonoids extract of $P$. pulchellum were obtained by ultrasonic extraction procedure. The ultrasonic extraction conditions were investigated based on the quantitative research of the total flavonoids using UV-Vis spectrophotometry from our previous experiment (data not published). Specifically, the dried P. pulchellum (5 g) was extracted with ultrasonic in small eggplant-type bottle with $71 \%$ ethanol $(150 \mathrm{~mL})$ at $80{ }^{\circ} \mathrm{C}$ for $1 \mathrm{~h}$. The extract was evaporated in a rotary evaporator at $40{ }^{\circ} \mathrm{C}$ to dryness, and the residue was dissolved in $5 \mathrm{~mL}$ of $71 \%$ ethanol. This sample was filtered through a $0.22 \mu \mathrm{m}$ syringe filter before subjected to HPLC-LTQ-Orbitrap-MS. There were 8 compounds that were isolated from $P$. pulchellum that were used as reference standards, including (-)-gallocatechin (compound 3), (+)-catechin (compound 4), (-)-epicatechin (compound 6), dihydroquercetin (compound 7), (+)-dihydrokaempferol (compound 8) quercetin (compound 9), rutin (compound 10), and quercetin-3-O- $\alpha$-L-rhamnopyranoside- $(1 \rightarrow 6)-\beta$-D-galactopyranosyl (compound 11).

An Agilent series 1290 Infinity HPLC instrument coupled with an LTQ/Orbitrap mass spectrometer equipped with an electrospray (ESI) interface was performed to analyze the total flavonoids extract. The chromatography conditions were as follows: a Kromasil C-18 analytical HPLC column $(250 \mathrm{~mm} \times 4.6 \mathrm{~mm}$, I.D., $5 \mu \mathrm{m})$ was used; the flow rate was $1.0 \mathrm{~mL} \cdot \mathrm{min}^{-1}$; the sample injection volume was $10 \mu \mathrm{L}$; the column temperature was $30^{\circ} \mathrm{C}$; and the diode-array detector (DAD) scanned from 190 to $400 \mathrm{~nm}$, and the samples were detected at $254 \mathrm{~nm}$. The gradient profile of mobile phase A (acetonitrile) and mobile phase B (0.1\% formic acid-water) was as follows: $0-10 \mathrm{~min}$, 5-10\% A; 10-20 min, 10-20\% A; 20-30 min, 20-50\% A; 30-50 min, 50-70\% A; 50-60 min, 70-80\% A; and 60-65 $\mathrm{min}, 80-100 \% \mathrm{~A}$. The LTQ-Orbitrap-MS operating parameters were as follows: drying gas, high-purity nitrogen $\left(\mathrm{N}_{2}\right)$; capillary temperature, $350^{\circ} \mathrm{C}$; source voltage, $3000 \mathrm{~V}$; sheath gas flow, 40 arb; aux gas flow, $10 \mathrm{arb}$; and tube lens, $-100 \mathrm{~V}$. Each sample was analyzed in both positive and negative modes so as to provide abundant information for structural identification. The mass spectra were recorded across the range of $m / z$ 100-1500, with accurate mass measurement of all of the mass peaks. Accurate mass measurements of each peak from the total ion chromatogram (TIC) were obtained by means of ESI source. All of the data were processed using Xcalibur software version 3.0 (Thermo Fisher Scientific, San Jose, CA, USA).

The quantification of the isolated flavonoids was carried out by high performance liquid chromatography using a semi-quantitative analysis method. Rutin (purity $>92.6 \%$ ) was used as a standard. The samples and standard were dissolved in ethanol (HPLC grade) and filtered using $0.22 \mu \mathrm{m}$ sterile Millex filters before injection. Aliquots of $10 \mu \mathrm{L}$ were injected into the HPLC system.

\section{Results and Discussion}

\subsection{Hepatoprotective and Antioxidant Activities of Organic Fractions}

Four fractions, PPP, PPE, PPB, and PPA, were obtained and evaluated for their hepatoprotective and antioxidant activities. Among them, PPE and PPB showed better hepatoprotective activities against human normal hepatocyte cell line L-O2 injured by D-GalN, with the cell viability value of $64.09 \%$ and $57.25 \%$ at $50 \mu \mathrm{M} \cdot \mathrm{mL}^{-1}$, respectively, while the PPA was $51.58 \%$ and the PPP was $49.47 \%$ at $50 \mu \mathrm{M} \cdot \mathrm{mL}^{-1}$. Meanwhile, PPE and PPB showed stronger antioxidant activities for being able to 
scavenge DPPH radicals with the $\mathrm{IC}_{50}$ values of 36.1 and $64.0 \mu \mathrm{g} \cdot \mathrm{mL}^{-1}$, respectively, compared with PPP with the $\mathrm{IC}_{50}$ values of $90.9 \mu \mathrm{g} \cdot \mathrm{mL}^{-1}$ and $264.1 \mu \mathrm{g} \cdot \mathrm{mL}^{-1}$, respectively.

\subsection{Structure Characterization of the Isolated Compounds from Ethyl Acetate Fraction (PPE) and n-Butanol} Fraction (PPB)

Nineteen compounds (compounds 1-19) were isolated from PPE and PPB, of which 9 flavonoids (flavonoids 1-9) were obtained from PPE, and 2 flavonoids (flavonoids 10 and 11) and 8 alkaloids (alkaloids 12-19) from PPB (Figure 1). Compounds 1-11 were flavonoids with different substitution patterns. Compound $\mathbf{1}$ was isolated as a light brown powder and was assigned a molecular formula of $\mathrm{C}_{24} \mathrm{H}_{20} \mathrm{O}_{9}$ on the basis of its NMR and ESI-MS data, which indicated 15 degrees of unsaturation. The ${ }^{1} \mathrm{H}-\mathrm{NMR}$ spectrum of compound 1 displayed signals for 2 olefinic protons at $\delta_{\mathrm{H}} 7.47(\mathrm{~d}, J=15.9 \mathrm{~Hz})$ and $6.23(\mathrm{~d}, J=15.9 \mathrm{~Hz}), 5$ aromatic protons at $\delta_{\mathrm{H}} 5.95-6.75,2$ methines at $\delta_{\mathrm{H}} 5.45(\mathrm{~m})$ and $4.93(\mathrm{br} \mathrm{s})$, and 1 methylene at $\delta_{\mathrm{H}} 2.96(\mathrm{dd}, J=17.3,4.6 \mathrm{~Hz})$ and $2.84(\mathrm{dd}, J=17.3,2.0 \mathrm{~Hz})$. The ${ }^{13} \mathrm{C}-\mathrm{NMR}$ and DEPT spectra of compound 1 indicated the presence of 24 carbons, including 1 carbonyl carbon at $\delta_{\mathrm{C}} 168.6,18$ aromatic carbons at $\delta_{\mathrm{C}} 95.8-157.8,2$ olefinic carbons at $\delta_{\mathrm{C}} 133.7$ and 115.1, 2 methines at $\delta_{\mathrm{C}} 78.4$ and 69.8 , and 1 methylene at $\delta_{\mathrm{C}}$ 26.7. These data suggested that compound 1 comprised a flavan skeleton with a 3,5,7,3', $4^{\prime}, 5^{\prime}$-hexasubstitution pattern, and was identified as (-)-epigallocatechin 3-O-(E)-p-coumaroate, based on its NMR data and rotation data, $\alpha_{\mathrm{D}}^{22}:-204.5(\mathrm{MeOH})$ [22]. The other flavonoids were also determined based on their NMR and ESI-MS data, as (-)-epigallocatechin 3-O-(Z)-p-coumaroate (flavonoid 2) [23], (-)-gallocatechin (flavonoid 3) [24], (+)-catechin (flavonoid 4) [22], (-)-epigallocatechin (flavonoid 5) [25], (-)-epicatechin (flavonoid 6) [22], dihydroquercetin (flavonoid 7) [26], (+)-dihydrokaempferol (flavonoid 8) [27], quercetin (flavonoid 9) [28], rutin (flavonoid 10) [29], and quercetin-3-O- $\alpha$-L-rhamnopyranosyl-(1 $\rightarrow 6)-\beta$-D-galactopyranoside (flavonoid 11) [30], respectively (see Supporting Information). All of the flavonoids 1-11 were isolated from P. pulchellum for the first time, and flavonoids 1, 2, 8, and $\mathbf{1 1}$ were obtained from the genus Phyllodium initially.

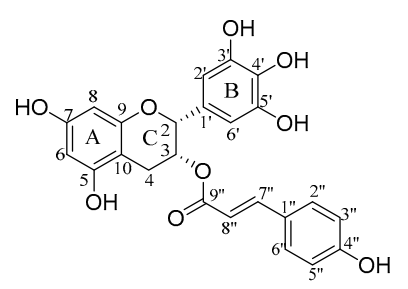

1<smiles>[R]c1cc([C@H]2Oc3cc(O)cc(O)c3C[C@H]2O)cc(O)c1O</smiles>

$6 \mathrm{R}=\mathrm{H}$
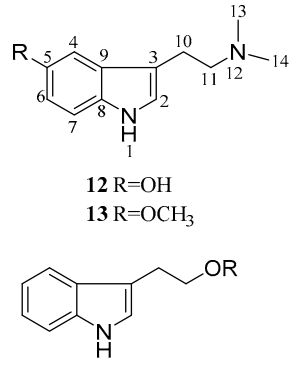

$18 \mathrm{R}=\alpha-L-\mathrm{Rha}-(1 \rightarrow 6)-\beta-D-\mathrm{Glc}$ $19 \mathrm{R}=\beta-D-\mathrm{Glc}$<smiles>O=C(O)C1Cc2c(O)cc(O)cc2OC1c1cc(O)c(O)c(O)c1</smiles>

2<smiles>[R]c1cc([C@H]2Oc3cc(O)cc(O)c3C(=O)[C@H]2O)ccc1O</smiles>

$7 \mathrm{R}=\mathrm{OH}$

$8 \mathrm{R}=\mathrm{H}$

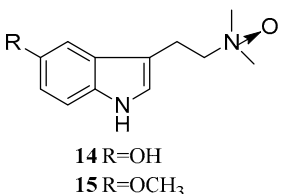

$10 \mathrm{R}=\alpha-L-\mathrm{Rha}-(1 \rightarrow 6)-\beta-D-\mathrm{Glc}$

$11 \mathrm{R}=\alpha-L-\mathrm{Rha}-(1 \rightarrow 6)-\beta-D-G \mathrm{al}$
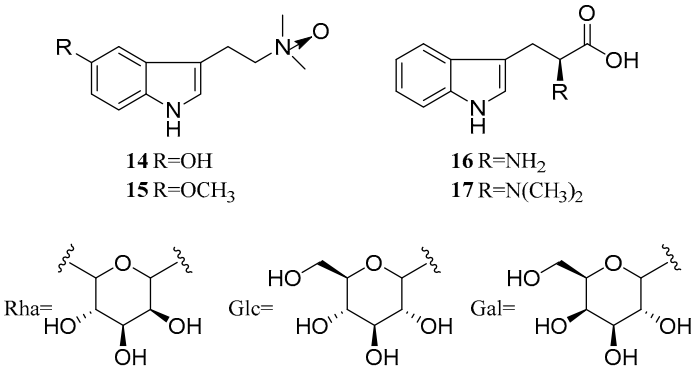

Figure 1. Structures of compounds 1-19, isolated from P. pulchellum. 
Compounds 12-19 were a series of indole alkaloids. Compound 12 was obtained as a colorless crystal. Its molecular formula was determined to be $\mathrm{C}_{12} \mathrm{H}_{16} \mathrm{~N}_{2} \mathrm{O}$ (six degrees of unsaturation), based on its ${ }^{1} \mathrm{H}$ - and ${ }^{13} \mathrm{C}-\mathrm{NMR}$ spectra, combined with the ESI-MS data. The ${ }^{1} \mathrm{H}-\mathrm{NMR}$ spectrum displayed signals for 1 indole nitrogen proton at $\delta_{\mathrm{H}} 9.82(\mathrm{~s}), 1$ olefinic proton at $\delta_{\mathrm{H}} 6.33(\mathrm{~s})$, 3 aromatic protons at $\delta_{\mathrm{H}} 6.44(\mathrm{~d}, J=8.6 \mathrm{~Hz}), 6.15(\mathrm{~d}, J=2.0 \mathrm{~Hz})$, and $5.93(\mathrm{dd}, J=8.6,2.0 \mathrm{~Hz})$, 2 methylenes at $\delta_{\mathrm{H}} 2.05(2 \mathrm{H}, \mathrm{m})$ and $1.82(2 \mathrm{H}, \mathrm{m})$, and 2 methyl groups at $\delta_{\mathrm{H}} 1.54(\mathrm{~s})$. The ${ }^{13} \mathrm{C}$-NMR and DEPT spectra of compound 12 indicated the presence of 12 carbons, including 6 aromatic carbons at $\delta_{\mathrm{C}} 150.2,130.9,128.0,111.7,111.3$, and 102.3; 2 olefinic carbons at $\delta_{\mathrm{C}} 123.0$ and 111.5; 2 methylenes at $\delta_{\mathrm{C}} 60.0$ and 23.2; and 2 methyl groups at $\delta_{\mathrm{C}} 45.1$ and 45.1. Based on the above analysis, compound 12 was identified as 5-hydroxy- $N, N$-dimethyltryptamine, which was identical to the reported data [31]. Subsequently, compounds 13-19 were identified as 5-methoxy- $N, N$-dimethyltryptamine (compound 13) [32], 5-hydroxy- $N, N$-dimethyltryptamine-oxide (compound 14) [33], 5-methoxy- $N, N$-dimethyltryptamine-oxide (compound 15) [13], L-tryptophan (compound 16) [34], N,N-dimethyl-L-tryptophan (compound 17) [35], 2-(indol-3-yl)ethyl- $\alpha$-L-

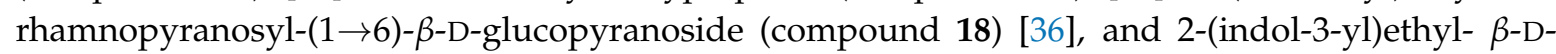
glucopyranoside (compound 19) [37] (see Supporting Information). Alkaloids 16-19 were isolated from P. pulchellum for the first time, and alkaloid 18 was obtained from the genus Phyllodium initially.

\subsection{Hepatoprotective Activity of the Isolated Compounds}

All of the isolated compounds 1-19 were tested for their hepatoprotective activities against the human normal hepatocyte cell line L-O2 injured by D-GalN. The results indicated that flavonoids 5 and 6 exhibited observably hepatoprotective activity, with higher cell viability values $(65.53 \%$ and $62.40 \%$ at $10 \mu \mathrm{M} \cdot \mathrm{mL}^{-1}$, respectively) than the positive control, silymarin $\left(61.85 \%\right.$ at $\left.10 \mu \mathrm{M} \cdot \mathrm{mL}^{-1}\right)$. Interestingly, alkaloid $\mathbf{1 8}$ was also found to show hepatoprotective activity, with the cell viability value of $60.72 \%$ at $10 \mu \mathrm{M} \cdot \mathrm{mL}^{-1}$, which was close to the positive control. According to the above results, it could be presumed that P. pulchellum displaying hepatoprotective activity might have been as a result of the presence of active compounds, mainly in the PPE and PPB fractions, such as compounds 5,6 , and 18.

A literature survey revealed that the flavonoids that were isolated from P. pulchellum, such as yukovanol and 8-prenylated 5,7,3', $4^{\prime}$-tetrahydroxy flavanone, could have inhibited the proliferation of the activated hepatic stellate cells (HSC-T6 cells), in vitro at $10 \mu \mathrm{M} \cdot \mathrm{L}^{-1}$, with cell viability values of $54 \%$ and $42 \%$, respectively [14]. In addition, flavonoid pulcheloid B was reported to exhibit potent inhibitory activity in vitro against the proliferation of acetaldehyde-stimulated HSC-T6 cells, with the $\mathrm{IC}_{50}$ value of $7.6 \mathrm{mM}$ [16]. Our study further proved that flavonoids had the hepatoprotective activity, which indicated that, besides the alkaloids, the flavonoids might have also been the potential pharmacodynamic ingredients that were responsible for the hepatoprotective activity of P. pulchellum.

\subsection{Antioxidant Activity of the Isolated Compounds}

A literature survey revealed that the hepatoprotective activity might have been related to antioxidant activity $[38,39]$. In the present study, the isolated compounds $\mathbf{1}-\mathbf{1 9}$ were further tested for their antioxidant activities against DPPH radicals. Only the flavonoids (-)-gallocatechin (compound 3) and (-)-epigallocatechin (compound 5) displayed strong antioxidant activities with the $\mathrm{IC}_{50}$ values of 3.8 and $4.0 \mu \mathrm{g} \cdot \mathrm{mL}^{-1}$, respectively, which were more potent than the positive control, vitamin $\mathrm{C}$ $\left(\mathrm{IC}_{50}: 5.1 \mu \mathrm{g} \cdot \mathrm{mL}^{-1}\right)$ (Table 1). Our results showed that flavonoids not only exhibited prominent hepatoprotective activity, but that they also displayed strong antioxidant activity. By comparison of the activities of flavonoids 3-6, we found that flavonoids $\mathbf{3}$ and $\mathbf{5}$ showed stronger activity than flavonoids 4 and 6, respectively. Furthermore, compound $7\left(\mathrm{IC}_{50}: 47.5 \mu \mathrm{g} \cdot \mathrm{mL}^{-1}\right)$ displayed a stronger activity than that of compound $8\left(\mathrm{IC}_{50}:>300 \mu \mathrm{g} \cdot \mathrm{mL}^{-1}\right)$. These results could have demonstrated that hydroxyl at $\mathrm{C}-5^{\prime}$ might have played an important role in antioxidant activity, which was consistent with previous reports $[40,41]$. Of flavonoids $\mathbf{1}, \mathbf{2}$, and $\mathbf{5}$, compound $\mathbf{5}$ with a hydroxyl substitution at $\mathbf{C}-3$ demonstrated 
higher activity, which indicated that the hydroxyl group at C-3 had a positive contribution to improving the activity rather than the $p$-hydroxy-cinnamic acid substitution. Additionally, compared with compound 9, the glycoside substitutions of compounds $\mathbf{1 0}$ and $\mathbf{1 1}$ reduced the activity. Based on the above results, it could have been inferred that the extracts with better antioxidant activity might have been as a result of the active compounds contained in PPE fraction, such as flavonoids 1-7 and 9.

There was no report regarding the antioxidant activity of the flavonoids from P. pulchellum. Interestingly, the flavonoids that were isolated from the ethanol extract of the Distylium racemosum branches, including compounds 3-6 and 9, which were the same as our study, were also evaluated for their antioxidant activities [42]. Particularly, compounds 3, 5, and 9 were reported for their radical scavenging activities toward $\mathrm{DPPH}$, with the $\mathrm{IC}_{50}$ values of $6.7,62$, and $65.3 \mu \mathrm{g} \cdot \mathrm{mL}^{-1}$, respectively [42], which were weaker than our test. While compounds 4 and 6 were found to display DPPH radical scavenging activities with the $\mathrm{IC}_{50}$ values of 7.2 and $6.3 \mu \mathrm{g} \cdot \mathrm{mL}^{-1}$, respectively [42], which were stronger than our study. Thus, it was necessary to carry out the in vivo antioxidant experiment of the isolated compounds.

Table 1. 1,1-Diphenyl-2-picrylhydrazyl (DPPH)-scavenging activity of compounds 1-19 from P. pulchellum $(n=5)$.

\begin{tabular}{cccc}
\hline Compounds & $\mathrm{DPPH} / \mathrm{IC}_{\mathbf{5 0}}\left(\boldsymbol{\mu g} \cdot \mathbf{m L}^{-\mathbf{1}}\right)$ & Compounds & $\mathrm{DPPH} / \mathrm{IC}_{\mathbf{5 0}}\left(\boldsymbol{\mu g} \cdot \mathbf{m L}^{-\mathbf{1}}\right)$ \\
\hline $\mathbf{1}$ & $36.1 \pm 2.1$ & $\mathbf{1 1}$ & $>300$ \\
$\mathbf{2}$ & $33.5 \pm 1.3$ & $\mathbf{1 2}$ & $>300$ \\
$\mathbf{3}$ & $3.8 \pm 0.14$ & $\mathbf{1 3}$ & $>300$ \\
$\mathbf{4}$ & $32.8 \pm 0.85$ & $\mathbf{1 4}$ & $>300$ \\
$\mathbf{5}$ & $4.0 \pm 0.09$ & $\mathbf{1 5}$ & $>300$ \\
$\mathbf{6}$ & $29.0 \pm 1.15$ & $\mathbf{1 6}$ & $>300$ \\
$\mathbf{7}$ & $47.5 \pm 2.7$ & $\mathbf{1 7}$ & $>300$ \\
$\mathbf{8}$ & $>300$ & $\mathbf{1 8}$ & $>300$ \\
$\mathbf{9}$ & $35.2 \pm 2.6$ & $\mathbf{1 9}$ & $>300$ \\
$\mathbf{1 0}$ & $>300$ & Vitamin C & $5.1 \pm 0.09$ \\
\hline
\end{tabular}

\subsection{HPLC-LTQ-Orbitrap-MS Analysis of Total Flavonoids}

To characterize the flavonoids in P. pulchellum, a HPLC-LTQ-Orbitrap-MS method was established. The total ion chromatograms (TIC) in negative ion mode (A) and positive ion mode (B) are displayed in Figure 2. Most of the constituents were well separated under the gradient elution condition, with high resolution and good sensitivity.

A total of 34 flavonoids, including 11 isolated flavonoids (flavonoids 1-11), were identified or tentatively characterized using our established analysis method (Figure 2 and Table 2). Among them, 8 compounds were confirmed with the isolated flavonoids as references, including (-)-gallocatechin (compound 3), (+)-catechin (compound 4), (-)-epicatechin (compound 6), dihydroquercetin (compound 7), (+)-dihydrokaempferol (compound 8) quercetin (compound 9), rutin (compound 10), and quercetin-3-O- $\alpha$-L-rhamnopyranoside- $(1 \rightarrow 6)-\beta$-D-galactopyranosyl (compound 11). The structures of 23 other flavonoids were tentatively characterized based on their retention times, HR-ESIMS data, and fragment ions, referring to databases (representative databases: SciFinder and KNApSAcK Core System) and literatures [43-46]. All of the identified 34 flavonoids had not been reported previously from P. pulchellum. These flavonoids that were characterized by HPLC-LTQ-Orbitrap-MS included 6 flavones (peaks 10, 15, 16, 19, 27, and 33), 11 flavonols (peaks 8, 9,11, 12, 13, 17, 20, 23, 24, 28, and 32), 6 flavan-3-ols (peak 1, 2, 4, 6, 18, and 22), 3 isoflavones (peaks 25, 29, and 31), 2 chalcones (peaks 5 and 26), 3 flavanonols (peak 7, 14, and 21), 1 dihydroflavone (peak 3), 1 flavan-3,4-diols (peak 30), and 1 xanthone (peak 34). To the best of our knowledge, it was the first time that the chemical constituents of flavonoids in P. pulchellum had been thoroughly and systematically investigate using HPLC-LTQ-Orbitrap-MS analysis, which would have provided a basis for further study of P. pulchellum, such as its metabonomics. 
Table 2. Identification of 34 flavonoids in the ethanol extract of P. pulchellum by high-performance liquid chromatography-linear ion trap quadrupole-Orbitrap-mass spectrometry (HPLC-LTQ-Orbitrap-MS)

\begin{tabular}{|c|c|c|c|c|c|c|c|}
\hline \multirow{2}{*}{ No. } & \multirow{2}{*}{ Rt. (min) } & \multirow{2}{*}{ Identification } & \multirow{2}{*}{ Formula } & \multicolumn{2}{|c|}{ Negative Ion $(\mathrm{m} / \mathrm{z})$} & \multicolumn{2}{|c|}{ Positive Ion $(\mathrm{m} / \mathrm{z})$} \\
\hline & & & & Quasi-Molecular & MS/MS (m/z) & Quasi-Molecular & MS/MS $(m / z)$ \\
\hline $1^{\mathrm{a}}$ & 11.02 & (-)-Gallocatechin (compound 3) & $\mathrm{C}_{15} \mathrm{H}_{14} \mathrm{O}_{7}$ & $305.0622[\mathrm{M}-\mathrm{H}]^{-}$ & $\begin{array}{c}287\left[\mathrm{M}-\mathrm{H}-\mathrm{H}_{2} \mathrm{O}\right]^{-} \\
261\left[\mathrm{M}-\mathrm{H}-\mathrm{H}_{2} \mathrm{O}-\mathrm{O}^{2-}\right]^{-} \\
221[\mathrm{M}-\mathrm{H}-\mathrm{A}]^{-} \\
179[\mathrm{M}-\mathrm{H}-\mathrm{B}]^{-} \\
137\left[\mathrm{M}-\mathrm{H}-\mathrm{C}_{8} \mathrm{H}_{8} \mathrm{O}_{4}\right]^{-}\end{array}$ & $307.0806[\mathrm{M}+\mathrm{H}]^{+}$ & $\begin{array}{l}289 \\
181 \\
139\end{array}$ \\
\hline 2 & 16.13 & (-)-Epigallocatechin (compound 5) & $\mathrm{C}_{15} \mathrm{H}_{14} \mathrm{O}_{7}$ & $305.0661[\mathrm{M}-\mathrm{H}]^{-}$ & n.a. & $307.0825[\mathrm{M}+\mathrm{H}]^{+}$ & $\begin{array}{l}289 \\
181 \\
139\end{array}$ \\
\hline 3 & 16.85 & 5-Hydroxyl liquiritin & $\mathrm{C}_{21} \mathrm{H}_{22} \mathrm{O}_{10}$ & $433.2018[\mathrm{M}-\mathrm{H}]^{-}$ & $\begin{array}{c}387\left[\mathrm{M}-\mathrm{H}-\mathrm{CO}-\mathrm{H}_{2} \mathrm{O}\right]^{-} \\
353[\mathrm{M}-\mathrm{H}-\mathrm{A}]^{-} \\
293 \\
271\left[\mathrm{M}-\mathrm{H}-\mathrm{C}_{6} \mathrm{H}_{11} \mathrm{O}_{5}\right]^{-}\end{array}$ & n.a. & n.a. \\
\hline $4^{\mathrm{a}}$ & 17.52 & (+)-Catechin (compound 4) & $\mathrm{C}_{15} \mathrm{H}_{14} \mathrm{O}_{6}$ & $289.0674[\mathrm{M}-\mathrm{H}]^{-}$ & $\begin{array}{c}271\left[\mathrm{M}-\mathrm{H}-\mathrm{H}_{2} \mathrm{O}\right]^{-} \\
245\left[\mathrm{M}-\mathrm{H}-\mathrm{CO}_{2}\right]^{-} \\
205\left[\mathrm{M}-\mathrm{H}-\mathrm{A}^{-}\right. \\
179\left[\mathrm{M}-\mathrm{H}-\mathrm{C}_{6} \mathrm{H}_{6} \mathrm{O}_{2}\right]^{-}\end{array}$ & $291.0878[\mathrm{M}+\mathrm{H}]^{+}$ & $\begin{array}{l}273 \\
246 \\
165 \\
139\end{array}$ \\
\hline 5 & 19.41 & Coreopsin & $\mathrm{C}_{21} \mathrm{H}_{22} \mathrm{O}_{10}$ & $433.2014[\mathrm{M}-\mathrm{H}]^{-}$ & $\begin{array}{c}415\left[\mathrm{M}-\mathrm{H}-\mathrm{H}_{2} \mathrm{O}\right]^{-} \\
397\left[\mathrm{M}-\mathrm{H}-\mathrm{H}_{2} \mathrm{O}^{-}\right. \\
297\left[\mathrm{M}-\mathrm{H}-\mathrm{C}_{7} \mathrm{H}_{5} \mathrm{O}_{3}\right]^{-} \\
161[\mathrm{glc}]^{-}\end{array}$ & n.a. & n.a. \\
\hline $6^{\mathrm{a}}$ & 20.80 & (-)-Epicatechin (compound 6) & $\mathrm{C}_{15} \mathrm{H}_{14} \mathrm{O}_{6}$ & $289.0675[\mathrm{M}-\mathrm{H}]^{-}$ & $\begin{array}{c}245\left[\mathrm{M}-\mathrm{H}-\mathrm{CO}_{2}\right]^{-} \\
205\left[\mathrm{M}-\mathrm{H}-\mathrm{A}^{-}\right. \\
179\left[\mathrm{M}-\mathrm{H}-\mathrm{C}_{6} \mathrm{H}_{6} \mathrm{O}_{2}\right]^{-}\end{array}$ & $291.0874[\mathrm{M}+\mathrm{H}]^{+}$ & n.a. \\
\hline 7 & 21.08 & Dihydrokaempferol-7-O- $\beta$-D-glucoside & $\mathrm{C}_{21} \mathrm{H}_{22} \mathrm{O}_{11}$ & $449.1023[\mathrm{M}-\mathrm{H}]^{-}$ & $\begin{array}{c}287\left[\mathrm{M}-\mathrm{H}-\mathrm{glc}^{-}\right. \\
267\left[\mathrm{M}-\mathrm{H}-\mathrm{glc}^{-}-\mathrm{H}_{2} \mathrm{O}\right]^{-} \\
259[\mathrm{M}-\mathrm{H}-\mathrm{glc}-\mathrm{CO}]^{-}\end{array}$ & n.a. & n.a. \\
\hline 8 & 23.05 & Gossypetin 7-rhamnoside-8-glucoside & $\mathrm{C}_{27} \mathrm{H}_{30} \mathrm{O}_{17}$ & $625.1320[\mathrm{M}-\mathrm{H}]^{-}$ & $\begin{array}{c}316[\mathrm{M}-\mathrm{H}-\mathrm{glc}-\mathrm{rha}]^{-} \\
271[\mathrm{M}-\mathrm{H}-\mathrm{glc}-\mathrm{rha} \\
-\mathrm{OH}-\mathrm{CO}]^{-}\end{array}$ & $627.1585[\mathrm{M}+\mathrm{H}]^{+}$ & $\begin{array}{l}481 ; \\
319\end{array}$ \\
\hline 9 & 23.39 & Quercetin-7-O-glucopyranoside & $\mathrm{C}_{21} \mathrm{H}_{20} \mathrm{O}_{12}$ & $463.0815[\mathrm{M}-\mathrm{H}]^{-}$ & $301\left[\mathrm{M}-\mathrm{H}-\mathrm{glc}^{-}\right.$ & $465.1043[\mathrm{M}+\mathrm{H}]^{+}$ & 303 \\
\hline 10 & 24.23 & Viscidulin II 2'-O-glucoside & $\mathrm{C}_{23} \mathrm{H}_{26} \mathrm{O}_{12}$ & $493.1289[\mathrm{M}-\mathrm{H}]^{-}$ & $\begin{array}{c}331\left[\mathrm{M}-\mathrm{H}-\mathrm{glc}^{-}\right. \\
313\left[\mathrm{M}-\mathrm{H}-\mathrm{C}_{6} \mathrm{H}_{12} \mathrm{O}_{6}\right]^{-} \\
271\left[\mathrm{M}-\mathrm{H}-\mathrm{glc}-\mathrm{OCH}_{3}\right]^{-}\end{array}$ & n.a. & n.a. \\
\hline
\end{tabular}


Table 2. Cont

\begin{tabular}{|c|c|c|c|c|c|c|c|}
\hline \multirow{2}{*}{ No. } & \multirow{2}{*}{ Rt. (min) } & \multirow{2}{*}{ Identification } & \multirow{2}{*}{ Formula } & \multicolumn{2}{|c|}{ Negative Ion $(\mathrm{m} / \mathrm{z})$} & \multicolumn{2}{|c|}{ Positive Ion $(m / z)$} \\
\hline & & & & Quasi-Molecular & MS/MS $(m / z)$ & Quasi-Molecular & MS/MS $(m / z)$ \\
\hline $11^{\mathrm{a}}$ & 25.06 & Rutin (compound 10) & $\mathrm{C}_{27} \mathrm{H}_{30} \mathrm{O}_{16}$ & $609.1379[\mathrm{M}-\mathrm{H}]^{-}$ & $301\left[\mathrm{M}-\mathrm{H}-\mathrm{C}_{12} \mathrm{H}_{20} \mathrm{O}_{9}\right]^{-}$ & $611.1638[\mathrm{M}+\mathrm{H}]^{+}$ & 303 \\
\hline 12 & 25.54 & Morin-7-O-glucopyranoside & $\mathrm{C}_{21} \mathrm{H}_{20} \mathrm{O}_{12}$ & $463.0891[\mathrm{M}-\mathrm{H}]^{-}$ & $301.0454\left[\mathrm{M}-\mathrm{H}-\mathrm{glc}^{-}\right.$ & $465.1047[\mathrm{M}+\mathrm{H}]^{+}$ & 303 \\
\hline 13 & 26.04 & Kaempferol 3-O-rutinoside & $\mathrm{C}_{27} \mathrm{H}_{30} \mathrm{O}_{15}$ & $593.1428[\mathrm{M}-\mathrm{H}]^{-}$ & $\begin{array}{l}327\left[\mathrm{M}-\mathrm{H}-\mathrm{C}_{12} \mathrm{H}_{20} \mathrm{O}_{10}\right]^{-} \\
285\left[\mathrm{M}-\mathrm{H}-\text { rutinoside }^{-}\right.\end{array}$ & $595.1683[\mathrm{M}+\mathrm{H}]^{+}$ & $\begin{array}{l}449 \\
287\end{array}$ \\
\hline $14^{\mathrm{a}}$ & 26.33 & Dihydroquercetin (compound 7) & $\mathrm{C}_{15} \mathrm{H}_{12} \mathrm{O}_{7}$ & $303.0462[\mathrm{M}-\mathrm{H}]^{-}$ & $\begin{array}{c}285\left[\mathrm{M}-\mathrm{H}-\mathrm{H}_{2} \mathrm{O}\right]^{-} \\
259\left[\mathrm{M}-\mathrm{H}-\mathrm{CO}_{2}\right]^{-} \\
177\left[\mathrm{M}-\mathrm{H}-\mathrm{C}_{8} \mathrm{H}_{4} \mathrm{O}_{6}\right]^{-}\end{array}$ & $305.0673[\mathrm{M}+\mathrm{H}]^{+}$ & n.a. \\
\hline 15 & 26.55 & Luteolin 7-O-rutinoside & $\mathrm{C}_{27} \mathrm{H}_{30} \mathrm{O}_{15}$ & $593.1425[\mathrm{M}-\mathrm{H}]^{-}$ & $285[\mathrm{M}-\mathrm{H}-\text { rutinoside }]^{-}$ & $595.1456[\mathrm{M}+\mathrm{H}]^{+}$ & $\begin{array}{l}449 \\
287\end{array}$ \\
\hline 16 & 26.67 & Kaempferol-7-O-glucoside & $\mathrm{C}_{21} \mathrm{H}_{20} \mathrm{O}_{11}$ & $447.0870[\mathrm{M}-\mathrm{H}]^{-}$ & $285[\mathrm{M}-\mathrm{H}-\mathrm{glc}]^{-}$ & $449.1093[\mathrm{M}+\mathrm{H}]^{+}$ & $\begin{array}{l}287 ; \\
172\end{array}$ \\
\hline $17^{\mathrm{a}}$ & 26.83 & $\begin{array}{c}\text { Quercetin-3-O- } \alpha \text {-L- } \\
\text { rhamnopyranoside-(1 } \rightarrow 6)- \\
\beta \text {-D-galactopyranosyl (compound 11) }\end{array}$ & $\mathrm{C}_{27} \mathrm{H}_{30} \mathrm{O}_{16}$ & $609.1372[\mathrm{M}-\mathrm{H}]^{-}$ & $301\left[\mathrm{M}-\mathrm{H}-\mathrm{C}_{12} \mathrm{H}_{20} \mathrm{O}_{9}\right]^{-}$ & $611.1627[\mathrm{M}+\mathrm{H}]^{+}$ & n.a. \\
\hline 18 & 27.00 & $\begin{array}{c}\text { (-)-Epigallocatechin } \\
\text { 3-O-(E)-p-coumaroate (compound 1) }\end{array}$ & $\mathrm{C}_{24} \mathrm{H}_{20} \mathrm{O}_{9}$ & $451.0968[\mathrm{M}-\mathrm{H}]^{-}$ & $\begin{array}{c}433\left[\mathrm{M}-\mathrm{H}-\mathrm{H}_{2} \mathrm{O}\right]^{-} \\
357\left[\mathrm{M}-\mathrm{H}-\mathrm{C}_{5} \mathrm{H}_{3} \mathrm{O}_{2}\right]^{-} \\
341 ; \\
311 \\
217 \\
\end{array}$ & $453.1194[\mathrm{M}+\mathrm{H}]^{+}$ & n.a. \\
\hline 19 & 27.28 & $\begin{array}{l}\text { 5,7,2-Trihydroxy-6-methoxyflavone } \\
\text { 7-O- } \beta \text {-D-glucoside }\end{array}$ & $\mathrm{C}_{22} \mathrm{H}_{22} \mathrm{O}_{11}$ & $461.1028[\mathrm{M}-\mathrm{H}]^{-}$ & $\begin{array}{c}446\left[\mathrm{M}-\mathrm{H}-\mathrm{CH}_{3}\right]^{-} \\
299[\mathrm{M}-\mathrm{H}-\mathrm{glc}]^{-}\end{array}$ & $463.1251[\mathrm{M}+\mathrm{H}]^{+}$ & $\begin{array}{l}445 ; \\
301\end{array}$ \\
\hline 20 & 27.40 & Quercetin-3,7-di-O-glucopyranoside & $\mathrm{C}_{27} \mathrm{H}_{30} \mathrm{O}_{17}$ & $625.1410[\mathrm{M}-\mathrm{H}]^{-}$ & $301\left[\mathrm{M}-\mathrm{H}-\mathrm{glc}-\mathrm{glc}^{-}\right.$ & $627.2453[\mathrm{M}+\mathrm{H}]^{+}$ & n.a. \\
\hline $21^{\mathrm{a}}$ & 27.51 & Dihydrokaempferol (compound 8) & $\mathrm{C}_{15} \mathrm{H}_{12} \mathrm{O}_{6}$ & $287.0521[\mathrm{M}-\mathrm{H}]^{-}$ & $\begin{array}{r}269\left[\mathrm{M}-\mathrm{H}-\mathrm{H}_{2} \mathrm{O}\right]^{-} \\
243\left[\mathrm{M}-\mathrm{H}-\mathrm{CO}_{2}\right]^{-} \\
161\left[\mathrm{M}-\mathrm{H}-\mathrm{C}_{6} \mathrm{H}_{6} \mathrm{O}\right]^{-} \\
\end{array}$ & $289.0719[\mathrm{M}+\mathrm{H}]^{+}$ & 272 \\
\hline 22 & 27.73 & $\begin{array}{l}\text { (-)-Epigallocatechin } \\
\text { 3-O-(Z)-p-coumaroate (compound 2) }\end{array}$ & $\mathrm{C}_{24} \mathrm{H}_{20} \mathrm{O}_{9}$ & $451.0975[\mathrm{M}-\mathrm{H}]^{-}$ & $\begin{array}{c}433\left[\mathrm{M}-\mathrm{H}-\mathrm{H}_{2} \mathrm{O}^{-}\right. \\
407\left[\mathrm{M}-\mathrm{H}-\mathrm{CO}_{2}\right]^{-} \\
357\left[\mathrm{M}-\mathrm{H}-\mathrm{C}_{5} \mathrm{H}_{3} \mathrm{O}_{2}\right]^{-} \\
305\left[\mathrm{M}-\mathrm{H}-\mathrm{C}_{9} \mathrm{H}_{6} \mathrm{O}_{2}\right]^{-} \\
287\left[\mathrm{M}-\mathrm{H}-\mathrm{C}_{9} \mathrm{H}_{8} \mathrm{O}_{3}\right]^{-} \\
269\left[\mathrm{M}-\mathrm{H}-\mathrm{C}_{9} \mathrm{H}_{6} \mathrm{O}_{4}\right]^{-} \\
229 ; \\
163\left[\mathrm{M}-\mathrm{H}-\mathrm{C}_{9} \mathrm{H}_{8} \mathrm{O}_{4}\right]^{-}\end{array}$ & $453.1199[\mathrm{M}+\mathrm{H}]^{+}$ & $\begin{array}{l}435 \\
327 \\
289 \\
247 \\
139\end{array}$ \\
\hline $23^{a}$ & 28.46 & Quercetin (compound 9) & $\mathrm{C}_{15} \mathrm{H}_{10} \mathrm{O}_{7}$ & $301.0311[\mathrm{M}-\mathrm{H}]^{-}$ & $\begin{array}{c}273\left[\mathrm{M}-\mathrm{H}-\mathrm{CO}^{-}\right. \\
257[\mathrm{M}-\mathrm{H}-\mathrm{OH}]^{-} \\
151\left[\mathrm{M}-\mathrm{H}-\mathrm{C}_{8} \mathrm{H}_{7} \mathrm{O}_{3}\right]^{-}\end{array}$ & $303.0509[\mathrm{M}+\mathrm{H}]^{+}$ & n.a. \\
\hline
\end{tabular}


Table 2. Cont

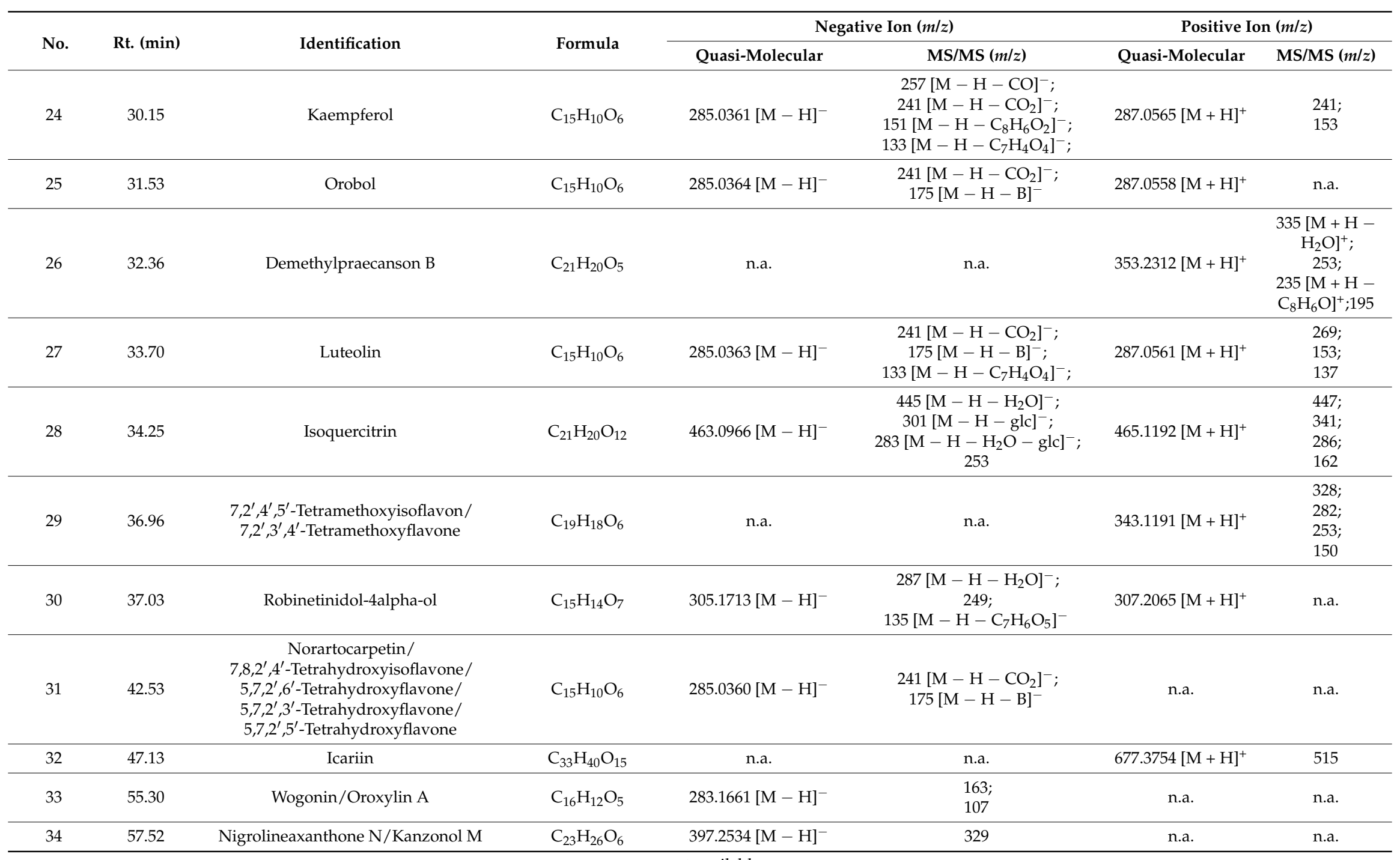

n.a.: not available. 

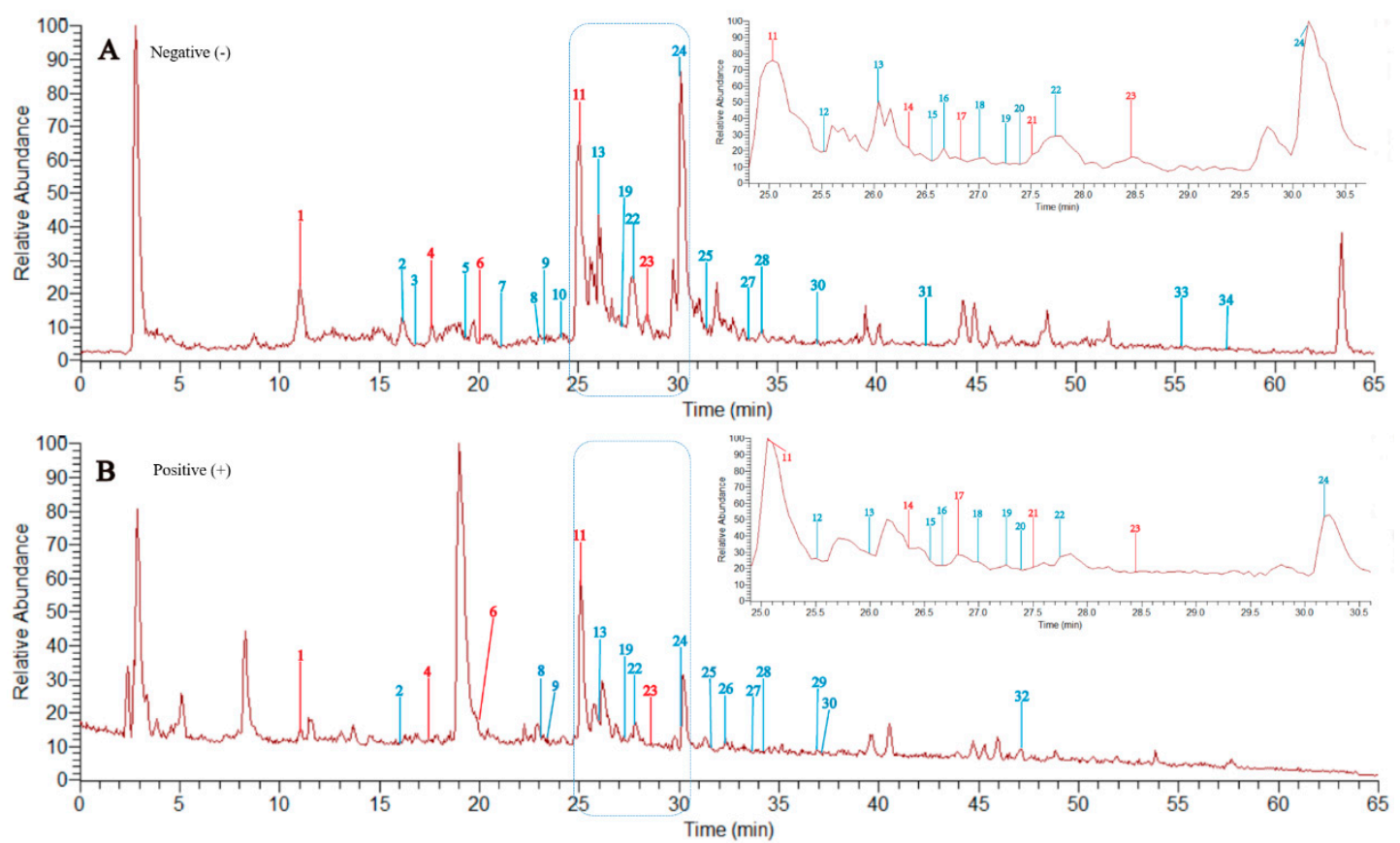

Figure 2. The total ion chromatograms (TIC) of the total flavonoids of P. pulchellum by high-performance liquid chromatography-linear ion trap quadrupole-Orbitrap-mass spectrometry (HPLC-LTQ-Orbitrap-MS) in negative ion mode (A) and positive ion mode (B). The compounds that are confirmed with the isolated reference compounds are marked in red.

In addition, we performed a semi-quantitative analysis of the isolated flavonoids. The contents of compounds 1-11 were 3.88, 17.73, 140.35, 41.93, 27.80, 4.34, 0.01, 0.20, 9.67, 795.85, and 5.23 $\mu \mathrm{g} \cdot \mathrm{g}^{-1}$, respectively. In our previous study, the quantitative investigation gave a total flavonoids content of $24.213 \mathrm{mg} \cdot \mathrm{g}^{-1}$ of P. pulchellum using UV-Vis spectrophotometry (data not published).

\section{Conclusions}

In summary, we investigated the pharmacodynamic ingredients of P. pulchellum, focusing on the flavonoids and their hepatoprotective and antioxidant activities. A phytochemical investigation of the active fractions of PPE and PPB from the ethanol extract of P. pulchellum led to the isolation of 11 flavonoids (flavonoids 1-11). The semi-quantification by HPLC showed that P. pulchellum might have possessed large quantities of flavonoids. Besides the isolated flavonoids, further investigation on the total flavonoids of P. pulchellum by HPLC-LTQ-Orbitrap-MS led to the discovery of 23 other flavonoids. All of the characterized 34 flavonoids were reported from P. pulchellum for the first time. These findings not only confirmed the abundant flavonoids in P. pulchellum, but also enriched the chemical composition library of this species.

In our study, the isolated flavonoids were found to exhibit prominent hepatoprotective and antioxidant activities, which was suggestive of the potential pharmacodynamic components of $P$. pulchellum. Specifically, flavonoids 5 and 6 exhibited observably hepatoprotective activity, with higher cell viability values than the positive control, silymarin. In addition, in our previous study, flavonoids 1-3, 5, 7, and 9 showed DNA topoisomerase I (Topo I) inhibitory activity at a concentration of $100 \mu \mathrm{M}$. Particularly flavonoids $\mathbf{1}$ and $\mathbf{2}$ still exhibited potent inhibitory activity, even at $5 \mu \mathrm{M}$ [47]. In general, the flavonoids showed significant biological activities, which should be important pharmacodynamic ingredients of P. pulchellum. Further investigation of flavonoids and alkaloids were suggested in order to explore the effects and mechanisms of thepharmacodynamic components from P. pulchellum in more detail. 
Supplementary Materials: The following are available online.

Author Contributions: C.-Y.W. (corresponding author) conceived and proposed the idea. Y.-C.F., S.-J.Y. and Z.-L.G. designed the study. Y.-C.F. and Z.-L.G. performed the experiments. Y.-C.F., S.-J.Y., Z.-L.G., and C.-Y.W. participated in the data analysis. C.-Y.W., H.-S.G., L.-T.X. and D.-L.Z. contributed to writing, revising, and proof-reading the manuscript. All of the authors read and approved the final manuscript.

Acknowledgments: We would like to thank Xue-Mei Hou (Ocean University of China) for critically reading a previous version of this manuscript. This work was supported by the National High Technology Research and Development Program of China (863 Program) (No. 2013AA093001), the Ocean Public Welfare Program, the State Oceanic Administration of China (201405038), the Scientific and Technological Innovation Project that was financially supported by the Qingdao National Laboratory for Marine Science and Technology (No. 2015ASKJ02), and the Taishan Scholars Program, China.

Conflicts of Interest: The authors declare no conflict of interest.

\section{References}

1. Editorial Board of Flora of China. Flora of China; Science Publishing House: Beijing, China, 2010; Volume 10, p. 266.

2. Chopra, R.N.; Nayar, S.L.; Chopra, I.C. Glossary of Indian Medicinal Plants; CSIR: New Delhi, India, 1956; p. 94.

3. Rahman, M.K.; Barua, S.; Islam, M.F.; Islam, M.R.; Sayeed, M.A.; Parvin, M.S.; Islam, M.E. Studies on the anti-diarrheal properties of leaf extract of Desmodium puchellum. Asian Pac. J. Trop. Biomed. 2013, 3, 639-643. [CrossRef]

4. Yu, S.M.; Zhong, M.; Huang, L.Y.; Zhang, Q.Q.; Yang, Z.Y. The effect of Desmodium pulchellum on the content of liver collagen protein of testing hepatic fibrosis rats. Hunan Zhongyiyao Daobao 1999, 5, 36-37.

5. Wei, Y.Q.; Zhong, M.; Zhang, S.Q.; Meng, J.Q.; Li, Z.G. Effect of Desmodium pulchellum and compound Tri-herb capsule on $\mathrm{O}_{2}{ }^{-}$. Mod. J. Integr. Tradit. Chin. West. Med. 2003, 12, 795-796.

6. Shen, C.C.; Wang, S.T.; Tsai, S.Y.; Yang, H.C.; Shieh, B.J.; Chen, C.C. Cinnamylphenols from Phyllodium pulchellum. J. Nat. Prod. 2005, 68, 791-793. [CrossRef] [PubMed]

7. Ghosal, S.; Banerjee, S.K.; Bhattacharya, S.K.; Sanyal, A.K. Chemical and pharmacological evaluation of Desmodium pulchellum. Planta Med. 1972, 21, 398-409. [CrossRef] [PubMed]

8. Rogova, L.S.; Gilev, A.P. Antiarrhythmic properties of some indolalkylamines. Bull. Exp. Biol. Med. 1968, 66, 1113-1114.

9. Zhong, M.; Yang, Z.Y.; Huang, L.Y.; Yu, S.M.; Lei, S. Effects of Desmodium pulchellum (L.) Benth total alkaloids on hepatic fibrosis rats' liver pathological and ultrastructure changes induced by chemical. Chin. J. Gastroenterol. Hepatol. 2001, 9, 168-170.

10. Zhong, M.; Yu, S.M.; Nong, C.Z.; Yang, Z.Y.; Huang, L.Y.; Chen, S.F. Effects of Desmodium pulchellum (L.) benth total alkaloids on col-I and col-III gene expression of hepatic fibrosis in Rats. Chin. J. Integr. Tradit. West. Med. Liver Dis. 2003, 13, 272-274.

11. Huang, J.L.; Zhong, M.; Yu, S.M. Effects of total alkaloids from Phyllodium pulchellum on proliferation of human hepatic stellate cells and collagen, cytokines related to hepatic fibrosis. Chin. J. Exp. Tradit. Med. Formulae 2013, 19, 283-286.

12. Cai, L.; Wang, C.; Huo, X.K.; Dong, P.P.; Zhang, B.J.; Zhang, H.L. Effect of alkaloids isolated from Phyllodium pulchellum on monoamine levels and monoamine oxidase activity in rat brain. Evid.-Based Complement. Altern. Med 2016, 1-5. [CrossRef]

13. Ghosal, S.; Mukherjee, B. Indole-3-alkylamine bases of Desmodium pulchellum. J. Org. Chem. 1966, 31, 2284-2288. [CrossRef]

14. Wang, C.; Zhong, M.; Zhang, B.J.; Huo, X.K.; Huang, S.S.; Yu, S.M.; Ma, X.C. Chemical constituents against hepatic fibrosis from Phyllodium pulchellum roots. Zhongyaocai 2014, 37, 424-426. [PubMed]

15. Fan, Y.C.; Guo, Z.L.; Xin, L.T.; Yue, S.J.; Bai, H.; Wang, C.Y. Chemical constituents from Phyllodium pulchellum. Zhongchengyao 2017, 39, 1195-1198.

16. Zong, Y.; Zhong, M.; Li, D.M.; Zhang, B.J.; Mai, Z.P.; Huo, X.K.; Huang, S.S.; Zhang, H.L.; Wang, C.; Ma, X.C.; Yu, S.M.; Yang, D.A. Phenolic constituents from the roots of Phyllodium pulchellum. J. Asian Nat. Prod. Res. 2014, 16, 1-6. [CrossRef] [PubMed] 
17. Tiwari, R.D.; Bansal, R.K. Physcion 1-glycosyl rhamnoside from seeds of Desmodium pulchellum. Phytochemistry 1971, 10, 1921-1922. [CrossRef]

18. Sinha, M.P.; Tiwari, R.D. The structure of a galactomannan from the seeds of Desmodium pulchellum. Phytochemistry 1970, 9, 1881-1883. [CrossRef]

19. Zhong, M.; Zhang, B.J.; Wang, C.; Yu, S.M.; Zong, Y.; Ma, X.C.; Zhang, H.L. Quality evaluation of Phllodium pulchellum. Zhongchengyao 2016, 38, 130-133.

20. Monks, A.; Scudiero, D.; Skehan, P.; Shoemaker, R.; Paull, K.; Vistica, D.; Hose, C.; Langley, J.; Cronise, P.; Vaigro-Wolff, A.; et al. Feasibility of a high-flux anticancer drug screen using a diverse panel of cultured human tumor cell lines. J. Natl. Cancer Inst. 1991, 83, 757-766. [CrossRef] [PubMed]

21. Nidhal, S.; Msaada, K.; Hamdaoui, G.; Limam, F.; Marzouk, B. Variation in phenolic composition and antioxidant activity during flower development of safflower (Carthamus tinctorius L). J. Agric. Food Chem. 2011, 59, 4455-4463.

22. Nonaka, G.; Kawahara, O.; Nishioka, I. Tannins and related compounds. XV. A new class of dimeric flavan-3-ol gallates, theasinensins A and B, and proanthocyanidin gallates from green tea leaf. (1). Chem. Pharm. Bull. 1983, 31, 3906-3914. [CrossRef]

23. Hashimoto, F.; Nonaka, G.I.; Nishioka, I. Tannins and related compounds. LVI isolation of four new acylated flavan-3-ols from oolong tea. (1). Chem. Pharm. Bull. 1987, 35, 611-616. [CrossRef]

24. Nonaka, G.I.; Nishioka, I.; Nagasawa, T.; Oura, H. Tannins and related compounds. I. rhubarb (1). Chem. Pharm. Bull. 1981, 29, 2862-2870. [CrossRef]

25. Yi, B.; Chen, T.; Feng, S.X.; Li, Q.H. Chemical constituents of Ancistrocladus tectorius. Guangxi Zhiwu 2013, 33, 564-567.

26. Wang, X.W.; Mao, Y.; Wang, N.L.; Yao, X.S. A new phloroglucinol diglycoside derivative from Hypericum japonicum Thunb. Molecules 2008, 13, 2796-2803. [CrossRef] [PubMed]

27. Xu, J.; Li, X.; Zhang, P.; Li, Z.L.; Wang, Y. Antiinflammatory constituents from the roots of Smilax bockii warb. Arch. Pharm. Res. 2005, 28, 395-399. [CrossRef] [PubMed]

28. Liu, M.C.; Yang, S.J.; Jin, L.H.; Hu, D.Y.; Wu, Z.B.; Yang, S. Chemical constituents of the ethyl acetate extract of Belamcanda chinensis (L.) DC roots and their antitumor activities. Molecules 2012, 17, 6156-6169. [CrossRef] [PubMed]

29. Han, J.T.; Bang, M.H.; Chun, O.K.; Kim, D.O.; Lee, C.; Baek, N.I. Flavonol glycosides from the aerial parts of Aceriphyllum rossii and their antioxidant activities. Arch. Pharm. Res. 2004, 27, 390-395. [CrossRef] [PubMed]

30. Oh, I.S.; Whang, W.K.; Kim, I.H. Constituents of Crataegus pinnatifida var. psilosa leaves (II)-Flavonoids from BuOH fraction. Arch. Pharm. Res. 1994, 17, 314-317. [CrossRef]

31. Somei, M.; Yamada, F.; Kurauchi, T.; Nagahama, Y.; Hasegawa, M.; Yamada, K.; Teranishi, S.; Sato, H.; Kaneko, C. The chemistry of indoles. CIII.1) simple syntheses of serotonin, $N$-methylserotonin, bufotenine, 5-methoxy- $N$-methyltryptamine, bufobutanoic acid, $N$-(indol-3-yl) methyl-5-methoxy- $N$-methyltryptamine, and lespedamine based on 1-hydroxyindole chemistry. Chem. Pharm. Bull. 2001, 49, 87-96. [CrossRef]

32. Gan, N.; Yang, X.; Li, T.H.; He, P. Studies on constituents of rootsanel leaves from Desmodium blandum and their cytotoxic activity against growth of several tum or cells. Zhongguo Zhongyao Zazhi 2008, 33, 2077-2080. [PubMed]

33. Zhang, P.; Cui, Z.; Liu, Y.S.; Sheng, Y. Isolation and identification of the indolealkylamines from the traditional Chinese medicine Toad Venom. J. Shenyang Pharm. Univ. 2006, 23, 216-219.

34. Li, G.Q.; Deng, Z.W.; Li, J.; Fu, H.Z.; Lin, W.H. Chemical constituents from starfish Asterias rollestoni. J. Chin. Pharm. Sci. 2004, 13, 81-86.

35. Sang, S.M.; Mao, S.L.; Lao, A.N.; Chen, Z.L. Studies on the chemical constituents of the seeds of Vaccariasegetalis (NECK) Garcke. III. Nat. Prod. Res. Dev. 2000, 12, 12-15.

36. Wang, C.H.; Zhang, Z.X.; Wang, Y.H.; He, X.J. Cytotoxic indole alkaloids against human leukemia cell lines from the toxic plant Peganum harmala. Toxins 2015, 7, 4507-4518. [CrossRef] [PubMed]

37. Yahara, S.; Shigeyama, C.; Ura, T.; Wakamatsu, K. Cyclic peptides, acyclic diterpene glycosides and other compounds from Lycium chinense MILL. Chem. Pharm. Bull. 1993, 41, 703-709. [CrossRef] [PubMed]

38. Devaraj, S.; Ismail, S.; Ramanathan, S.; Yam, M.F. Investigation of antioxidant and hepatoprotective activity of standardized Curcuma xanthorrhiza rhizome in carbon tetrachloride-induced hepatic damaged rats. Sci. World J. 2014. [CrossRef] [PubMed] 
39. Babu, B.H.; Shylesh, B.S.; Padikkala, J. Antioxidant and hepatoprotective effect of Acanthus ilicifolius. Fitoterapia 2001, 72, 272-277. [CrossRef]

40. Husain, S.R.; Cillard, J.; Cillard, P. Hydroxyl radical scavenging activity of flavonoids. Phytochemistry 1987, 26, 2489-2491. [CrossRef]

41. Miyake, T.; Shibamoto, T. Antioxidative activities of natural compounds found in plants. J. Agric. Food Chem. 1997, 45, 1819-1822. [CrossRef]

42. Ko, R.K.; Kim, G.O.; Hyun, C.G.; Jung, D.S; Lee, N.H. Compounds with tyrosinase inhibition, elastase inhibition and DPPH radical scavenging activities from the branches of Distylium racemosum Sieb. et Zucc. Phytother. Res. 2011, 25, 1451-1456. [CrossRef] [PubMed]

43. Xu, W.; Huang, M.Q.; Li, H.; Chen, X.W.; Zhang, Y.W.; Liu, J.; Xu, W.; Chu, K.D.; Chen, L. Chemical profiling and quantification of Gua-Lou-Gui-Zhi decoction by high performance liquid chromatography/quadrupole-time-of-flight mass spectrometry and ultra-performance liquid chromatography/triple quadrupole mass spectrometry. J. Chromatogr. B 2015, 986, 69-84. [CrossRef] [PubMed]

44. Vallverdú-Queralt, A.; Boix, N.; Piqué, E.; Gómez-Catalan, J.; Medina-Remon, A.; Sasot, G.; Mercader-Martí, M.; Llobet, J.M.; Lamuela-Raventos, R.M. Identification of phenolic compounds in red wine extract samples and zebrafish embryos by HPLC-ESI-LTQ-Orbitrap-MS. Food Chem. 2015, 181, 146-151. [CrossRef] [PubMed]

45. He, L.L.; Zhang, Z.F.; Lu, L.Y.; Liu, Y.; Li, S.; Wang, J.G.; Song, Z.J.; Yan, Z.G.; Miao, J.H. Rapid identification and quantitative analysis of the chemical constituents in Scutellaria indica L. by UHPLC-QTOF-MS and UHPLC-MS/MS. J. Pharm. Biomed. Anal. 2016, 117, 125-139. [CrossRef] [PubMed]

46. Gao, D.; Wang, B.J.; Huo, Z.P.; He, Y.; Polachi, N.; Lei, Z.D.; Liu, X.X.; Song, Z.H.; Qi, L.W. Analysis of chemical constituents in an herbal formula Jitong Ning Tablet. J. Pharm. Biomed. Anal. 2017, 140, 301-312. [CrossRef] [PubMed]

47. Xin, L.T.; Lu, L.; Shao, C.L.; Yu, R.L.; Chen, F.L.; Yue, S.J.; Wang, M.; Guo, Z.L.; Fan, Y.C.; Guan, H.S.; Wang, C.Y. Discovery of DNA topoisomerase I inhibitors with low-cytotoxicity based on virtual screening from natural products. Mar. Drugs 2017, 15, 217. [CrossRef] [PubMed]

Sample Availability: Samples of the compounds 1-19 are available from the authors.

(C) 2018 by the authors. Licensee MDPI, Basel, Switzerland. This article is an open access article distributed under the terms and conditions of the Creative Commons Attribution (CC BY) license (http:/ / creativecommons.org/licenses/by/4.0/). 